podstawy do powstania uczelni o charakterze uniwersyteckim.

Ten sam problem dotyczył kadry naukowej. Zagadnienie to, obok warunków materialnych przyszłego uniwersytetu w świetle doniesień prasowych, omówiła Autorka w rozdziale piątym. W kwestii kadry sugestie zmierzały do wykorzystania istniejącego potencjału kadrowego, przeniesienia całych wydziałów $z$ innych szkół wyższych (np. germanistyki z WSP w Zielonej Górze) oraz pozyskania kadr naukowych $z$ innych ośrodków.

Wystąpiły też liczne kontrowersje wokół warunków lokalowych i potrzeb materialnych w dość trudnej sytuacji ekonomicznej państwa.

Pracę D. Koźmian wieńczy rozdział szósty, który ukazuje powołanie Uniwersytetu Szczecinskiego Ustawą sejmową z dnia 21 lipca 1984 r.

Praca ta stanowi interesujące studium nad powstaniem uniwersytetu $w$ okresie formacji ustrojowej PRL, gdy racje polityczne i naukowe albo były sprzeczne, albo wzajemnie się uzupetniały, gdy przyjmowano konwencje partyjności nauki i jej politycznego charakteru. Polityczny aspekt godził także w pewnym sensie aspiracje naukowe w konkretnym przypadku Uniwersytetu Szczecińskiego, a związany był $\mathrm{z}$ faktem powołania do życia uniwersytetu na północno-zachodnich kresach państwa polskiego, przy granicy, wprawdzie z konieczności z zaprzyjażnionymi NRD-owcami, ale zawsze Niemcami. Z drugiej strony mógł się także stać placówką o najwyższej randze, współprzyczyniającą się do faktycznego zbliżenia pomiędzy
Polakami i Niemcami (wspólne badania naukowe, wzajemne wizyty pracowników nauki i studentów, wymienne studia, wspólne konferencje naukowe itp.). To teź był cel zarówno polityczny, jak i naukowy.

Wartość książki, w związku z tym, podnosi dobre tłumaczenie streszczenia $w$ języku niemieckim autorstwa Aliny Horajskiej.

Autorka kończy swe rozważania stwierdzeniem, iż „po piętnastu latach ... Uniwersytet Szczeciński jest już wpisany w pejzaż spoleczno-kulturalny Szczecina i regionu..." (s. 159).

Interesujace dywagacje zawarte w tej pracy są godne studiowania nie tylko $w$ regionie, ale stanowią dobrą podstawę do refleksji nad kształtowaniem szkół wyższych i uniwersytetów w czasach współczesnych. W szczególności obecnie, gdy w III Rzeczypospolitej powstaje wiele nowych zarówno państwowych, jak i prywatnych szkół wyższych, które poszukuja, na fali krytyki (momentami totalnej, bo są ku temu powody) swej drogi biegnącej często bardzo blisko granic naukowości i hochsztaplerstwa. Wiele istniejących obecnie uczelni w Polsce dąży także do nobilitacji poprzez projekty zmiany swych nazw na akademie, czy też uniwersytet.

Stąd też refleksje nad problemem powstawania współczesnego uniwersytetu zawarte w tej książce, odnoszące się wprawdzie do odmiennej formacji ustrojowej, mog̨ pomóc studiom nad dalszym rozwojem szkolnictwa wyższego w Polsce.

Jan Hellwig

\title{
Pedagogika spoleczna - pytania o XXI wiek. Pamięci Profesora Ryszarda Wroczyńskiego, pod red. A. Przeclawskiej i W. Theissa, Warszawa 1999, Wydawnictwo Akademickie „Żak”, ss. 194
}

„Dobiega końca wiek $\mathrm{XX}$, wiek energii jądrowej, wielkich kataklizmów i wielkich odkryć. Wraz z wiekiem XX - dobiega końca drugie tysiąclecie naszej ery. Za lat dwadzieścia pięć rozpocznie się trzecie tysiąclecie, a $w$ to tysiąclecie wkroczy ponad połowa współczesnej populacji. Jakie ono będzie - oto pytanie sta- wiane coraz powszechniej?". To słowa Ryszarda Wroczyńskiego, które zawarł w swojej, wydanej w 1975 roku, książce pt.: Edukacja permanentna.

Podobne pytanie, rozszerzone o refleksje nad kształtem i miejscem pedagogiki społecznej w naszym kraju, postawili sobie uczestnicy 
ogólnopolskiego seminarium: Pedagogika spoleczna - pytania o XXI wiek, które zorganizowała w dniach 24 - 25 listopada 1997 r. Katedra Pedagogiki Społecznej Wydziału Pedagogicznego Uniwersytetu Warszawskiego. Odpowiedzią na to pytanie jest publikacja, zawierająca wypowiedzi naukowców, zatytułowana: Pedagogika spoleczna - pytania o XXI wiek. Pamięci Profesora Ryszarda Wroczyńskiego, która dzięki Wydawnictwu Akademickiemu „Zak” ukazała się w 1999 roku.

Okresy przełomowe w historii zwykle nastrajają refleksyjnie i budza pewne obawy, stąd zrozumiałym jest zainteresownie $\mathrm{z}$ jakim spotkała się warszawska konferencja ze strony polskich pedagogów społecznych. Dodatkowym bodźcem były także przemiany społeczno-ekonomiczne, jakie zachodzq w naszym spoleczeństwie od kilku lat, związane $\mathrm{z}$ rewolucyjna zmianq systemu politycznego po 1989 roku. Data zorganizowania ogólnopolskiego seminarium nie została także ustalona spontanicznie i przypadkowo. W 1997 roku przypadła bowiem dziesiąta rocznica śmierci Profesora Ryszarda Wroczyńskiego oraz czterdziesta rocznica powstania Katedry Pedagogiki Spolecznej Uniwersytetu Warszawskiego.

Organizatorzy spotkania, redagując i ustalając tematykę i porządek obrad, przyjęli, iż znaczenie pedagogiki społecznej nie powinno być już dziś rozpatrywane $z$ ograniczonej perspektywy udziału wychowania jedynie w procesie transformacji ustrojowej i społecznej. Wychowanie i nauczanie bowiem jest „niezbędnym a niedocenianym czynnikiem dynamizowania rozwoju społecznego w warunkach cywilizacyjnych XXI wieku" (s. 12).

Związano tę złożoną tematykę $\mathrm{z}$ osobą Ryszarda Wroczyńskiego, który będąc pedagogiem spolecznym, historykiem oświaty i wychowania, profesorem Uniwersytetu Warszawskiego był jednocześnie, obok Heleny Radlińskiej i Aleksandra Kamińskiego, współtwórcą polskiej szkoły pedagogiki społecznej. Według organizatorów seminarium, mlodzi pedagodzy społeczni, kształtujący w nowych warunkach społecznych tożsamość swojej dyscypliny, winni właśnie czerpać $\mathrm{i}$ brać przykład $\mathrm{z}$ najlepszych, ponieważ „dziedzictwo naukowe Ryszarda Wroczyńskiego nie przemija Nadal inspiru- je i pomaga. Słuźy w pokonywaniu dystansu między tym, "co było" i tym "co będzie"; oddziela to, co istotne $\mathrm{i}$ ważne w edukacji od tego, co kusi blaskiem mody i koniunktury; mówi co to jest język faktów i konkretów, a co należy do myślowych spekulacji i mitów" (s. 11).

Publikacja Pedagogika spoleczna - pytania o XXI wiek. Pamieci Profesora Ryszarda Wroczyńskiego, pokłosie seminarium, została podzielona na trzy części. Pierwsza $z$ nich poświęcona jest osobie Profesora i zatytułowano ją: Ryszard Whoczyński - życie i dzielo. Rozpoczyna ja praca Wiesława Theissa, mówiąca o drodze naukowej $R$. Wroczyńskiego, o jego zainteresowaniach pozytywizmem, historią oświaty polskiej i powszechnymi dziejami wychowania fizycznego i sportu. Wreszcie W. Theiss omawia aktywność R. Wroczyńskiego na niwie pedagogiki społecznej, sposób w jaki, w trudnych powojennych latach, funkcjonowała ta dyscyplina naukowa. Autor przedstawia także profesora jako twórcę Katedry Pedagogiki Spolecznej UW i jako nauczyciela i jako dydaktyka. W trzecim podrozdziale swojej pracy przybliża koncepcje pedagogiki społecznej wg Wroczyńskiego, która zbudowana została na bazie jego zainteresowaí historycznych, teoretycznych studiów pedagogicznych i doświadczeń praktycznych zdobytych na polu pracy oświatowej. Koncepcja ta więc ma „charakter szerokiej i całościowej refleksji nad natura wychowania i rola, jaka w tym procesie odgrywa środowisko ludzkiego życia" (s. 24).

Kamilla Mrozowska w swoim artykule przedstawia Ryszarda Wroczyńskiego jako redaktora „Przeglądu Historyczno-Oświatowego" w latach 1959-1987. Ponieważ Profesor związany był $\mathrm{z}$ tym pismem od początku jego istnienia, praca $\mathrm{K}$. Mrozowskiej jest poniekąd także monografią „Przeglądu”. Powstało ono z inicjatywy nie środowisk naukowych, ale nauczycielstwa zaangażowanego $w$ tajnym nauczaniu w czasie okupacji niemieckiej. Powołane w latach 1945 - 46 z ramienia Głównego Związku Nauczycielsta Polskiego, pismo kierowane początkowo przez profesora UJ, Jana Hulewicza, zdołało wydać jedynie cztery numery, z czego nr 1 na polecenie cenzury zostal znisz- 
czony. Wydawnictwo zostało dopiero wznowione w 1959 roku, pod kierunkiem R. Wroczyńskiego. Pierwszy numer z 1959 roku nosił jednak liczbe 5. Nowemu redaktorowi zależało by pismo miało nie tylko wysoki poziom poznawczy, ale także informacyjny. Autorka w swoim artykule zwraca uwage na atmosfere pracy i spotkań redakcyjnych (często w mieszkaniu państwa Wroczyńskich). Sama będąc pracownikiem redakcji wspomina życzliwość i zaangażowanie Profesora nie tylko w sprawy związane $\mathrm{z}$ redagowniem pisma, ale także stosunki ze współpracownikami, „by wysiłek był rzeczywiście zespołowy" (s. 40).

Irena Lepalczyk, kolejna współautorka tomu, pisze o bardzo ważnym okresie życia R. Wroczyńskiego, o Jego pobycie w Lodzi, kiedy to poznal i zaczął współpracować z H. Radlińską Pod jej kierunkiem Profesor rozpocząl przygotowania do przewodu habilitacyjnego. Na Wydziale Humanistycznym UL habilitacja R. Wroczyńskiego w 1949 roku była piątą z kolei po wojnie, $w$ tym pierwszą z pedagogiki. Podstawę habilitacji stanowiła praca: Programy oświatowe pozytywizmu w Polsce na tle spolecznym $i$ gospodarczym. I. Lepalczyk w dalszej części swojego artykułu przybliża nam postać $R$. Wroczyńskiego jako dydaktyka, wykładowce i promotora wielu prac magisterskich, powstałych na Uniwresytecie Lódzkim. Kreśli również jego wizerunek jako przyjaciela prof. A. Kamińskiego.

Czesść tomu poświęcona Profesorowi Ryszardowi Wroczyńskiemu nie byłaby kompletna, gdyby zabrakło w niej osobistych wspomnień. Ich autorami sq prof. prof.: Wiesław Theiss, Stefan Wołoszyn, Tadeusz W. Nowacki, Józef Miąso, Kajetan Hądzelek, Irena Wojnar i Alicja Wrzesińska.

Część druga tomu nawiązuje już bezpośrednio do tytułu całej pracy, do problematyki współczesnej pedagogiki społecznej. Artykuł Anny Przecławskiej zatytułowany jest: Przestrzeń życia czlowieka - miedzy perspektywa mikro a makro. Autorka zamierzała w nim skupić się na analizie $i$ interpretacji pojęcia środowiska wychowawczego, co nie jest zadaniem łatwym, zważywszy na szybko zachodzące zmiany spoleczno-gospodarcze, tak na świecie, jak i w naszym kraju. Ponadto zwróciła uwage na znaczenie pedagogiczne terminu „środowisko wychowawcze" i socjologiczne dla pojęcia „przestrzeń życia". W swoich dalszych rozważaniach A. Przecławska snuła refleksję nad przestrzenią historyczna, nad tym co było, co jest i co będzie. Autorka stwierdziła, iż Polacy, jako naród, inaczej niż mieszkańcy Zachodu, nie interesują się historia, a także przyszłością, iż „kryzysy globalnego świata i wynikające stąd problemy sq ignorowane przez nasze społeczeństwo żyjace przede wszystkim $w$ atmosferze własnej, dokonującej się po upadku komunizmu, transformacji”. Stąd tak wielką rolę przypisuje autorka naukom pedagogicznym.

Refleksję nad współczesnym światem i społeczeństwem prezentuje także Tadeusz Frąckowiak. Tytuł jego artykułu to: Kontrowersje wokól świata wartosci a przeobrażenia spoleczne. Autor koncentruje się na wizerunku człowieka schylku epoki, w dobie „liberalnej doktryny”, piszącej scenariusze marnego dramatu o konturach tragizmu (...), gdzie pojęcia wolności i demokracji uległy zmąceniu albo melancholijnej krytyce - podobnie zresztą jak cały postmodernizm" (s. 88). T. Frąckowiak zastanawia się także, jaka filozofia życia byłaby najlepsza dla Polski i Polaków, omamionych i zafascynowanych od 1989 roku kulturą Zachodu. Jaki kierunek byłby najbezpieczniejszy dla polskich tradycji i kultury, w dobie koniecznej nowoczesności?

Ważne w pracy T. Frąckowiaka jest rozliczenie się z panującą do 1989 roku ideologią „wschodniego kolektywizmu”, który „ostatecznie doprowadził do rozpadu syntezy miedzy indywidualizmem a uczestnictwem spolecznym, odhumanizowania stosunków społecznych i prymitywizmu rzeczy oraz wartości" (s. 93). Stąd między innymi Polacy tak słabo są odporni na "rewolucję" spoleczno-gospodarcza ostatnich lat: na bezrobocie, urynkowienie, prywatyzacje itd. W takiej sytuacji zagrożone zostały wartości stanowiące o godności człowieka wraz $\mathrm{z}$ chroniącym je prawem naturalnym: prawem do wolności, życia, podstawowych dóbr, nienaruszalności fizycznej, psychicznej, prawem do swobody religijnej.

Kolejny artykuł, autorstwa Jerzego Nikitorowicza, dotyczy wielokulturowych wymiarów wychowania. Bo jak pisal Ryszard Wroczyński, 
wychowanie zawsze „stanowilo odzwierciedlenie rozwoju i potrzeb społeczeństwa na różnych poziomach kultury. Wiązało się z wizją przyszłej roli wychowanka w życiu" (s. 103). Jaki jest wobec tego dzisiejszy ideał wychowawczy i społeczny, w społeczeństwie wielokulturowym i globalnym? Czy najbezpieczniej nie byłoby zamknąc się „u siebie i ze swoimi"? Ale to tak jak byśmy żyli w stawie bez wymiany wody....

Konkluzje autora prowadzą $w$ kierunku uznania właśnie wychowania za pośrednika i mediatora między regionalizacją i globalizacją, wskazując jednocześnie na wszelkie niebezpieczeństwa i zalety przenikania się tego, co swojskie i tego, co obce.

Edukacja w środowisku $i$ jej zagrożenia to kolejny problem we współczesnej pedagogice społecznej. Zajęła się nim w swoim artykule Ewa Marynowicz-Hetka. Autorka zaproponowała, by zastanowić się nad społeczno-pedagogicznym wymiarem - odniesieniem działania w obszarze edukacji, uwzględniając kontekst społeczno-kulturowy, jej uwarunkowania tworzenia się i rozwoju. "Pytania o XXI wiek" sprowokowały E. Marynowicz-Hetke do podzielenia się pewnymi hipotezami odnoszącymi się do przebiegu i do tworzenia się edukacji w różnych środowiskach, społecznościach, czyli ogólnie mówiąc - w środowisku życia jednostki. Autorka w swoich rozważaniach za punkt wyjścia przyjęła definicję edukacji jako instytucji, która nie jest nam dana raz na zawsze, ale zmienia się wraz $\mathrm{z}$ nami. Jest to o tyle istotne, że żyjemy na kontynencie, zmierzającym do unifikacji gospodarczej, politycznej, monetarnej, społecznej, stąd pewna „mobilność" edukacyjna jest koniecznością.

Część drugą tomu pt: Pedagogika spoleczna zamyka artykuł Andrzeja Olubińskiego, zatytułowany: Sily spoleczne - szanse $i$ mity. Autor definiując pojęcie „sily" odwołał się do twórców polskiej szkoły pedagogiki społecznej: do $\mathrm{H}$. Radlińskiej, która to pojęcie wprowadziła, do R. Wroczyńskiego, który nadał polskiej pedagogice społecznej pozytywistyczna proweniencję, do A. Kamińskiego, który szukał sił społecznych w dażeniach $\mathrm{i}$ aspiracjach działaczy społecznych i młodzieżowych. Następnie A. Olubiński podjął próbę endogennego ujęcia sił społecznych środowiska, dążąc tym samym do ich pewnej systematyzacji. Jest to możliwe jedynie wtedy, gdy analizując siły spoleczne, będziemy jednocześnie identyfikować typ i kategorię środowiska, z którym mamy do czynienia, i jednocześnie rozpoznamy rodzaj dynami$z m u$, który te siły napędza.

Kolejnym zagadnieniem, jakim zajął się autor były relacje między siłami społecznymi a procesami wychowania. Problematyka ta daje dodatkowe możliwości pedagogicznej typologii środowiska wychowawczego, w oparciu o znaczenie poszczególnych sił, występujących w społeczeństwie.

Część trzecią tomu stanowią materiały nadesłane oraz glosy w dyskusji. Do pierwszych należą dwa artykuły: Edmunda Trempały - Edukacja ustawiczna - wymóg wspólczesnosici i Bogusława Chmielowskiego - Perspektywy pedagogiki spolecznej jako nauki wobec wyzwan cywilizacyjnych przelomu stuleci.

Pierwszy $\mathrm{z}$ autorów zwraca uwage na fakt rozszerzania się usług edukacyjnych poza szkoła, co jest wynikiem niewątpliwego i nieustannego wzrostu wiedzy. Encyklopedyzm, wynoszony przez dzieci ze szkoły staje się coraz bardziej uciążliwy i zbyteczny. Stąd szkoła winna wyposażać swoich uczniów w umiejętność ciągłego wzrastania intelektualnego, kulturalnego, moralnego i zawodowego w ciągu całego życia czlowieka.

Drugi z autorów, Bogusław Chmielowski, przedstawia perspektywy rozwoju nauki w zmieniającym się świecie, powotując się na poglądy i opinie znanych naukowców, często kontrowersyjne i niejednoznaczne, jak np.: Francisa Fukuyamy, który w 1992 roku obwieścił koniec historii, co wywołalo zamieszanie w środowiskach historyków. W tym świetle B. Chmielowski przedstawia perspektywy rozwoju pedagogiki społecznej, wskazując trzy obszary jej działalności. Pierwszy $z$ nich to próba przezwyciężenia pozostałości komunistycznego dziedzictwa, obecnego nie tylko w nauce, ale także w sposobie naszego myślenia. Drugi obszar to postulat powrotu do źródel (np.: przywrócenie dorobku polskiej pedagogiki społecznej lat międzywojennych), a trzeci - to zbudowanie nowego paradygmatu pedagogiki społecznej. 
Kończące tom glosy w dyskusji należały do: Wiesława Rogalskiego, Barbary Smolińskiej-Theiss, Zofii Zukowskiej, Mariusza Cichosza, Danuty Urbaniak-Zając i Jacka Piekarskiego. Treść tych wystapień i ożywiona wymiana poglądów wskazują jasno, iż prezen- towana książka jest jedynie wstẹpem do szerszej dyskusji i refleksji nad współczesną pedagogika społeczną I taka chyba była intencja redaktorów omawianego wydawnictwa.

Edyta Glowacka

\section{Andrzej Meissner, Spór o duszę polskiego nauczyciela. Spoleczeń- stwo galicyjskie wobec problemów ksztalcenia nauczycieli, Rzeszów 1999, Wyd. Wyższej Szkoly Pedagogicznej, ss. 380}

Z uznaniem trzeba przyjąc książke profesora Andrzeja Meissnera, zajmującego się dziejami oświaty w Galicji, zatytułowaną Spór o dusze polskiego nauczyciela. Spoleczenistwo galicyjskie wobec problemów ksztalcenia nauczycieli.

Publikacja stanowi 11 tom z serii Galicja $i$ jej dziedzictwo, w której autor podejmuje problematykę kształtowania się systemu kształcenia nauczycieli.

Jak pisze autor ksztaltowanie się współczesnego modelu szkół pedagogicznych miało miejsce w XIX w. w zwiazzk z rozwojem obowiązującej i ogólnoksztalcącej oświaty elementarnej traktowanej jako pierwszy szczebel nauczania $i$ torującej droge dalszej edukacji. Wymagało to przygotowania nauczycieli tak pod względem teoretycznym, jak i pedagogicznym.

Społeczeństwo polskie, pozostajace pod panowaniem trzech obcych państw, nie mogło decydować o kształcie szkolnictwa pedagogicznego, które podporzadkowane zostało systemowi oświatowemu zaborców.

Największe możliwości kształtowania rodzimej oświaty pojawiły się w zaborze austriackim w latach 60-tych XIX w. Kształcenie nauczycieli dla szkół ludowych stało się problemem nie tylko oświatowym, ale i politycznym. Whadze polityczne zdawały sobie sprawę, że dzięki powszechnemu nauczaniu elementarnemu, można kształtować poglady społeczne, wpajać określone wartości i wdrażać do pewnych określonych zachowań politycznych. W tym kontekście osoba nauczyciela nabierała szczególnego znaczenia. Autor w tytule książki - jak sądzę
- odwołuje się do dawidowskiej koncepcji osobowości nauczyciela, zawartej w rozprawie pt. O duszy nauczycielstwa, opublikowanej przez H. Rowida na łamach „Ruchu Pedagogicznego". J. W. Dawid dowodził w niej, że nauczyciel ma działać na ucznia jak człowiek na człowieka. Walka o rzad dusz nauczycielskich, szczególnie w Galicji, stała się jednym z bardzo ważnych elementów polityki oświatowej prowadzonej przez władze krajowe.

Dalsze zmiany $w$ dziedzinie elementarnej edukacji dokonaly się na początku XX w. (tuż przed I wojnz światowa) pod wplywem idei „Nowego Wychowania". Nauczyciela powinna "echować aktywność i twórczość zawodowa oraz dążenie do doskonalenia umiejętności nauczycielskich. Dyskusje w tej sprawie podejmowały różne środowiska społeczne, partie polityczne $i$ ich organy prasowe, jak również organizacje nauczycielskie, które najbardziej zainteresowane były prestiżem swojego zawodu.

System kształcenia nauczycieli dla potrzeb szkolnictwa galicyjskiego stanowił swoista mozaikę. $\mathrm{Na}$ wyróżnienie zasłużył niewątpliwie system kształcenia nauczycieli szkół ludowych, który był najbardziej zwarty organizacyjnie i programowo.

Intencja autora - jak sądze - było uzyskanie odpowiedzi na pytania: jak funkcjonował system kształcenia nauczycieli, w jakim stopniu relizowane były założenia tego systemu narzucone przez władze państwowe i krajowe, jak również, jakie efekty przynosiły założenia systemu kształcenia nauczycieli w wymiarze praktycznym i teoretycznym? 